Copyright (C) 2021 by Academic Publishing House Researcher s.r.o.

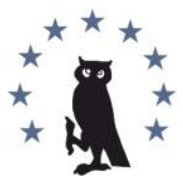

Published in the Slovak Republic

Media Education (Mediaobrazovanie)

Has been issued since 2005

ISSN 1994-4160

E-ISSN 2729-8132

2021. 17(1): $45-53$

DOI: $10.13187 / \mathrm{me} .2021 .1 .45$

www.ejournal53.com

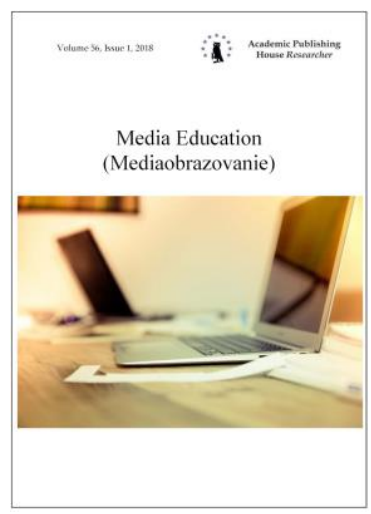

\title{
Programs and Projects for Fostering Interethnic Tolerance Among Youth: Foreign and Russian Experience
}

\author{
Irina Chelysheva a , *, Galina Mikhaleva a \\ a Rostov State University of Economics, Russian Federation
}

\begin{abstract}
The further development of the information society, the inclusion of media in all life spheres of modern youth allows us to consider media education as one of the productive means of fostering interethnic tolerance in the contemporary younger generation which opens up new opportunities for integrating media education technologies with multicultural education, thus forming a true culture of interethnic tolerance. This article presents the analysis of flagship programs and projects for promoting interethnic tolerance among young people through media education. The comparative analysis of the program content of Russian and foreign approaches to fostering interethnic tolerance in student youth by means of media education has enabled us to define the media education methods, forms, technologies and approaches aimed at fostering interethnic tolerance that can become a basis for further successful development in Russian conditions. The main materials for studying the issues of interethnic dialogue, the culture of different peoples and ethnic groups are feature films and documentaries, websites, social networks, television programs, articles in newspapers and magazines. Development of analytical skills and critical thinking skills, comprehension and interpretation of media production of various types and genres, media creative and media project activities of students are of fundamental importance for studying and comprehending interethnic tolerance by student youth.
\end{abstract}

Keywords: media, media education, interethnic tolerance, students, curriculum, university.

\section{Introduction}

The challenge of contemporary higher education based on the ideas of humanism is to help individuals to develop and improve in the awareness of their needs and interests. The university education should be subordinated to such upbringing aims as altruism, openness, respect for the other, solidarity and involvement in events that take place both within the walls of an educational organization and beyond. This trend is of particular importance in the context of educating future citizens who will have to be responsible for the state of affairs in the country and the world in the near future. Meanwhile, "the existing interethnic tension in the student environment reflects a certain social section of Russian society, and the conceptualization of these issues allows us to give a balanced assessment of the national-state policy currently implemented in the Russian Federation, including state program acts, managerial decisions, Russian legislation regulating ethnic relations in modern Russian society" (Garunova, Prosenyuk, 2018).

The media provide information about the events taking place in the world and largely determine the public opinion and value priorities of the younger generation. Acting as an important agent of socialization and inculturation, the media space contributes to the expansion of

\footnotetext{
* Corresponding author

E-mail addresses: ivchelysheva@yandex.ru (I.V. Chelysheva)
} 
interethnic ties, communication of people belonging to various nations and cultures. In this sense, it is difficult to overestimate the capabilities of media education which educational and upbringing potential is increasingly being actualized in present-day education, including higher education.

The analysis of modern studies of the issues has shown (Chelysheva, Mikhaleva, 2020) the constantly growing interest of the younger generation in media culture (television, press, cinema, Internet, radio, etc.), a significant impact that modern mass media have on students' worldview, life priorities and interests, and at the same time - wide opportunities that media education opens up for developing critical thinking, social adaptation in the context of a rapidly growing information flow.

In this article we attempt to analyze the flagship programs and projects for promoting interethnic tolerance among young people by means of media education based on the best Russian and foreign practices.

\section{Materials and methods}

The core materials of the article are the findings of the analysis and synthesis of modern curricula and projects for promoting interethnic tolerance among university students in Russia and abroad (using the example of some English-speaking countries). Research methods include analysis and synthesis of scientific sources on the research problem, generalization and classification.

\section{Discussion}

A number of programs have been developed to foster students' interethnic tolerance in modern Russian education. For example, the program developed by S.V. Alekhina and I.A. Anikina (Alekhina, Anikina, 2019). The authors of the program pay special attention to creating a multiethnic educational environment in a modern university that will act as a model for promoting tolerant relations among representatives of different nationalities and provide "a spiritually rich atmosphere of business and interpersonal contacts which determine the outlook, style of thinking and behaviour of people, motivate them to familiarize themselves with national and universal spiritual values; an institution with a multicultural contingent, including multi-age, multinational and multi-confessional faculty and students. The educational environment acting as a sociocultural factor promoting tolerance creates conditions for broadcasting culture, developing a new culture" (Alekhina, Anikina, 2019: 20). The program comprises a complex of activities for students including panel discussions, workshops, training exercises, group and team work, etc.

Also, we should mention some recent monographs devoted to the problem under study. For example, S.A. Domracheva, L.V. Lezhnina and N.S. Morova (Domracheva et al., 2017) have recently carried out a comprehensive study including the theoretical and practical issues of promoting intercultural tolerance among university students. The authors designed and implemented a number of university courses aimed at fostering intercultural tolerance among university students training for teachers and psychologists on the basis of the Mari State University.

The project of organizing a multicultural centre for continuing education at the Siberian Federal University is presented by A.K. Lukin (Lukin, 2015). This centre is an interactive space that carries out a number of activities aimed at promoting intercultural competence among university students by "teaching youth; developing integration strategies, creating opportunities for interaction and mutual understanding among indigenous people and migrants through various intercultural events (courses, exhibitions, conferences, seminars); conducting discussions, analytical seminars, panel discussions on issues related to civil values; promoting citizenship courses that help indigenous people and migrants learn about the environment in which they live; suggesting possible strategies for interaction between institutional and non-institutional services, schools and centres at the local level, nationally and internationally " (Lukin, 2015: 236-237).

Promoting interethnic tolerance among university students is also carried out in Russian clubs and volunteer organizations. Thus, I.V. Tolstoukhova (Tolstoukhova, 2019) describes the activities of the student interclub opened a few years ago at the Tyumen Industrial University. She emphasizes that interethnic tolerance can be fostered in a university through various forms of activities: these are classroom sessions relating about diversity and values of cultures, group lessons (in the form of a game where students get acquainted with different cultures), discussions, talks (for example, how to properly conduct an equal dialogue among ethnocultural representatives), elements of social and psychological training in the classroom. In terms of 
content, promoting interethnic tolerance can also be realized through university youth organizations providing support and cooperation in solving the problems of students belonging to different nationalities.

M.A. Kolokoltsova describes her experience in promoting university students' interethnic tolerance in the context of socio-cultural activities implemented at the Astrakhan State University (Kolokoltseva, 2017).

L.A. Apanasyuk analyses a number of regional programs for youth to overcome extremism and xenophobia and singles out several major directions, among which the author stands out: "the development of a harmonious state ideological concept of promoting tolerance and strengthening friendship of peoples as well as socio-cultural programs based on it; widespread use of educational technologies of social and cultural activities for emigrants to learn the basics of the Russian language and culture; active use of information and education technologies in social and cultural activities for intercultural communication and a positive image of migrants; use of sociocultural communication technologies for the intercultural dialogue between the indigenous population and newcomers through meaningfully adequate cultural and leisure programs; use of recreational and cultural-creative technologies for the equal interethnic dialogue and cooperation through festivals of national cultures, national holidays, educational programs telling about ethnocultural traditions, folklore, rituals and crafts; raising the status of national diasporas and communities in complex socio-cultural activities to overcome xenophobia" (Apanasyk, 2013).

Media literacy education of citizens in the social context is aimed at protecting people from negative media effects and at creating a tolerant mood in society: "Working with media texts of different types and genres contributes to the development of students' analytical skills in dealing with media information, activates creative skills of all the participants, improves their argumentation skills. Moreover, it improves the ability of the audience to take collective decisions by analysing the problem from different points of view which, no doubt, acts as an important means of promoting interethnic tolerance of the student audience" (Chelysheva, Mikhaleva, 2019: 388). Another, no less important trend is practical media work which in the present format stands for active participation and media production by citizens, especially young people. The content of such videos or films is based on real stories of people who suffered from social injustice, fought against discrimination, defended their rights, helped other people in trouble, gained success in professional life, etc. (Fedorov, Mikhaleva, 2020).

In present-day Canada, media education centres organize education activities for schoolchildren and university students aimed at promoting interethnic tolerance both in the legislative sphere and in issues of racial and interethnic discrimination. In this regard, media experts are developing programs to acquaint students with the state laws applied in the rights of citizens belonging to interethnic minorities and aborigines are violated.

Moreover, publications of scientific and methodological literature on media education and media culture, including manuals on promoting interethnic tolerance, master classes and advanced training courses for teachers are held in Canada. Media educators from different provinces is coordinated by the Canadian Association of Media Education Organizations (CAMEO) founded in 1992. The education and social-cultural activities of the association are aimed at developing critical thinking of the audience: "The skills of thinking critically about mass communication are essential survival skills in a technological, consumer society such as ours.” (Worsnop, 2004: 1).

A special role in Canada's media education belongs to another media education organization - Canada' Centre for Digital and Media Literacy - MediaSmarts which contributes to promoting media literacy in educational establishments, families and society. They bring together the various concepts and competencies that define what it is to be literate in today's complex media culture, and explore digital literacy and media literacy, their underlying aspects and principles. The issues of racial and interethnic tolerance are a separate area of work of this media education centre, including the analysis of racial and ethnic stereotypes on television, in cinema and in the press; fight against racism and hate speech on the Internet.

To this end, in recent years, a number of programs have been developed by this centre for media educators. The most famous of these are the media education programs Exploring Media \& Race and Deconstructing Online Hate. They include professional development workshops for teachers and students, lesson plans with discussion guides, interactive activities and student handouts. These programs are aimed at assisting teachers in mastering media education methods and technologies related to critical thinking in the context of racial or ethnic identity and diversity, 
analysing the language of media. These programs were designed to provide educators with powerful teaching tools to combat racism, interethnic and interethnic intolerance. In particular, the Exploring Media \& Race program was supposed to help the audience explore the role that mainstream media play in shaping perceptions about race or ethnicity and understand that all aspects of media production are created with a specific purpose and lobby for a specific point of view. The program also teaches youth about the impact that the representation and portrayal of visible minority groups and aboriginals on TV, in films, videogames, music videos and advertising can have on their perceptions about others in society. The Deconstructing Online Hate program teaches students learn to recognize subtle bias, racism and hate by showing them how hate mongers operate on the Internet. The program examines hateful content on Web sites, bulletin boards, chat rooms, blogs, e-mail, games and in music. The programs were produced and developed by MNet (Media Awareness Network) with the financial support of Canadian Heritage, Multiculturalism Program.

MNet is a non-profit Canadian organization whose mission is to support and encourage media and Internet education. Its aim is to help children and youth to develop an informed and critical understanding of the nature of the media, the techniques used in creating media products and the media's role and influence within society. In 2012, MNet launched a new suite of digital and media literacy resources to help educate young people about how media representations can negatively influence how we view certain groups in society. The Diversity and Media Toolbox, a web-based program for teachers, students, law enforcement representatives and the general public, looked at issues relating to stereotyping, bias and hate in mainstream media and the Internet. The program was broken into two distinct but complementary topic areas: online hate and media portrayals of ethnicity and race, religion, disability, sexual orientation and aboriginal people. "What young people see and hear in media helps them to understand the world, and who and what are valued in our society. The Internet, in particular, presents challenges to a tolerant, diverse society with its easily accessible messages of hate", said Jane Tallim, former Co-Executive Director of Media Awareness Network. "These new resources will help young people - who may lack life experience and critical development - to recognize and challenge stereotyping and hateful messaging in the media they consume" (Media Awareness Network, 2012). The Diversity and Media Toolbox, which comprises online tutorials, lessons, interactive student modules and background articles, provided teachers and students with free manuals and educational aids.

One of the worldly recognized leaders in media education is the British Film Institute. The support programs and initiatives for talented youth launched by the British Film Institute, together with the Department for Education and other partner organizations for young people aged 16-19, help to provide not only the technical training of future professionals, but also give them a unique opportunity to expand their knowledge in the field of media culture and cinema. In order to promote interethnic tolerance in the younger generation, specialists from the education department of the British Film Institute regularly hold workshops and seminars related, among other things, to the issues of racial and ethnic discrimination. For example, in October-November 2019, Dr Rona Murray conducted several workshops for teachers and students aimed at teaching the technologies of critical analysis of the cinema language. During the seminar on the topic "Representation - Critical Techniques: an A Level Study Day", the audience had an opportunity to identify the relationship between the genre specificity of the media text and its representation in historical, cultural and technological aspects. Using a range of film and television, the speaker explained to the audience some examples linked directly to gender, race, ethnicity, disability and regionality, and taught to consider how issues of representation interact with genre and authorship. The students used clips from films including: Get Out (2017), A Quiet Place (2018), Straight Outta Compton (2015) and the Marvel franchise and TV series including: The Bridge, Life on Mars and Atlanta to explore specific interactions such as horror and race, crime drama and gender, superhero and disability. This event was designed to support students' critical skills' development.

The method of critical analysis of media texts in the British tradition is based on such key concepts of media education as "media language", "media representation", "media categories", "media technologies" and "media agencies" (Bazalgette, 1992). This critical approach involves the analysis of genre stereotypes in media texts, the study of the historical, social, political and cultural contexts of media narration, etc. 
Currently, promoting interethnic tolerance in the younger generation does not lose its relevance in the United States either. The constant growth of interethnic intolerance as one of the leading and still unresolved challenges in the country's internal political space forces the state to act more actively and introduce social rules of tolerant coexistence of citizens of different ethnic groups. This process is carried out at different levels of education and is aimed at fostering interethnic tolerance of American schoolchildren and university students. For example, in addition to the course on the general history of America, educational establishments throughout the country regularly hold the so-called "black history month", also known as "African-American History Month" when every schoolchild or student is required to study facts from the life of famous historical figures of African American descent. The event has received official recognition from governments in the United States and Canada, and more recently has been observed in Ireland, the Netherlands, and the United Kingdom. It began as a way of remembering important people and events in the history of the African diaspora.

Alongside with supporting free, pluralistic and independent journalism, it is becoming clear in American society that promoting media and information literacy can help address today's challenges of radicalizing violent extremism. Since media literacy is inevitably connected to social, political and cultural life in the modern media environment, a great number of present-day scholars and researchers focus on studying human behaviour in social computer-mediated interactions and challenges of global cross-cultural communication (Buckingham, 2014; FrauMeigs et al.., 2017; Frau-Meigs, Torrent, 2009; Gálik, 2020; Livingstone, 2018; Mikhaleva, 2019; Ranieri, 2016; Reineck, Lublinski, 2015).

In this regard, more attention should be paid to promoting media and information literacy in a social sense, including the fight against intolerance and violent extremism through education in society. It is required to unite governments, educators, media, Internet companies, civil society and media users to create or improve systems, mechanisms, programs related to the media sphere to achieve this goal. In this regard, an increasingly important role in fostering interethnic tolerance of schoolchildren and university students in the USA is assigned to mass media education. The cornerstone in the upbringing and education of young people in matters of violating the principles of interethnic tolerance is, first of all, their discussing and analysing media content inciting intolerance with parents and teachers. In English-speaking countries, there are professional websites offering online media education resources for critical analysis of hate speech and the ideology of intolerance to help educators, parents and young people create a tolerant community.

\section{Results}

The potential of media education in fostering interethnic tolerance in modern youth is obvious. It is clear that among the challenges facing modern education is students' critical thinking, creative production and analysis of media texts. We agree with I.Z. Chimitova that "it is urgent to give a person the widest opportunities for an informed choice: a person should have the right to make a choice in favour of more positive, but no less interesting and exciting information than negative information about different peoples and cultures, about great works and their creators, about friendship, love, devotion, generosity, talents of people of different nationalities and citizenships, happy international families, etc. Of course, to realize this right, a person must take a more meaningful action than in the case when he or she is required to simply mindlessly consume information and succumb to suggestion, moreover, certain intellectual efforts are required from a person" (Chimitova, 2011).

Indeed, the possibilities of media education in promoting interethnic tolerance in the student audience have already firmly established themselves in Russian media education as an important factor in education, upbringing and development of the younger generation.

The research findings and the model for fostering students' interethnic tolerance through media education (Chelysheva, Mikhaleva, 2020) have enabled us to launch a university course for students - "Promoting interethnic tolerance through media education". The purpose of the program is to form the attitudes of interethnic tolerance in the student audience.

The main goals of the program include: analysis of theoretical issues related to interethnic tolerance; study of forms and media education activities for fostering interethnic tolerance (1992-2020); teaching students the basic forms, methods and techniques of media education activities in the context of promoting interethnic tolerance on the material of media culture of different types and genres. 
The course program for university students has a modular structure and includes two main sections: "Theoretical foundations of promoting interethnic tolerance through media education" and "Methods and technologies of media education in fostering students' interethnic tolerance".

The study of the theoretical material involves teaching students the essence and characteristics of the basic concepts of the program: ethnos, nation, interethnic tolerance, intercultural dialogue, national identity, intolerance, extremism, interethnic intolerance, "hate speech", etc.; study of the importance of promoting interethnic tolerance in the upbringing of the younger generation.

As a separate topic, the program helps students to examine the methodological foundations of fostering interethnic tolerance, including the issues of tolerance in the philosophical views of Russian and foreign researchers; cultural aspects of interethnic tolerance in scientific approaches; major psychological and pedagogical approaches to fostering interethnic tolerance; sociological and political science foundations of interethnic tolerance; methodological principles of studying interethnic tolerance. Of particular importance for the study of interethnic tolerance is given to the legal foundations of interethnic tolerance in the program content: the issues of interethnic tolerance in the documents of the world community and regulatory documents and resolutions of Russian legislation.

Another important aspect of studying interethnic tolerance is to acquaint the student audience with the history of promoting interethnic tolerance among student youth in Russia. The genesis of the main approaches to the problem under study includes considering the prerequisites for fostering interethnic tolerance laid down in the Soviet era: international education, its significance for further development of the intercultural dialogue, the genesis of interethnic tolerance in the years of "perestroika" and, finally, the current state and main prospects for promoting interethnic tolerance in Russian society (Chelysheva, Mikhaleva, 2019). Studying the history of interethnic tolerance within media education would be incomplete without addressing the historical aspects of interethnic tolerance abroad, in particular, in English-speaking countries. Hence, students have the opportunity to get acquainted with the main development stages of interethnic tolerance in Great Britain, Canada, the USA and other English-speaking countries, as well as with the modern trends in promoting interethnic tolerance.

Learning about the potential of media education in promoting interethnic tolerance, key theories of media education (aesthetic, sociocultural, development of critical thinking, semiotic, etc.), the main approaches to Russian and foreign media education, its trends and prospects is an important aspect of the training course for university students.

No less important for future teachers and psychologists will be the study of methods, forms, technologies of integrated media education aimed at fostering interethnic tolerance in young people in Russian and foreign media education. Media culture (fiction and documentary films, television programs, photography, advertising, websites, social networks, etc.) is the main material for studying.

The British model of media education has had a great influence on the content components of the program which involves developing critical thinking and applying a media creative approach based on the key concepts: "media agencies", "media categories", "media language", "media technologies", "media representations", "media audiences", etc.

We included such media education techniques as "sound and image", "spot the shots", "top and tail", "attracting audiences", "generic translations", "cross-media comparisons", "simulation" (Bazalgette, 1992; Chelysheva, Mikhaleva, 2020; Gálik, 2019; 2020; Kačinová, 2018; Petranová et al., 2017; Šupšáková, 2016).

When studying the issues of interethnic tolerance, ethnic identification and interethnic relations of representatives of different nationalities and cultures within the program, students learn to analyze and interpret the works of media culture of different types and genres: printed media, feature films and documentaries, photography, websites, social networks, social advertising, television programs related to interethnic relations.

Storytelling technology can become a very productive type of media education for the audience to identify themselves with the characters, authors, or even inanimate objects of a film about interethnic tolerance. This technology, which originates in media education in the United States and Canada, is already quite actively used in Russian media education. This method found its application even in film education in the study of literary film adaptations. 
The program also reflects some methods of developing media and information literacy used by foreign media educators in the context of promoting interethnic tolerance. Among them, the most promising are: the issue-enquiry approach (an example of this approach can be the study of interethnic and racial issues based on the analysis of media texts, the study of cyberbullying in the course of ethnographic research, etc.); problem-based learning which develops students' interdisciplinary knowledge and skills, as well as critical thinking and problem-solving strategies; scientific enquiry which involves making observations, posing questions, investigations, using tools to gather, analyze, and interpret data, proposing explanations and communicating the results (an example of using this method in the context of teaching interethnic tolerance is the study of the social consequences of hate speech in media texts); case-study which involves an in-depth examination of a single instance or event; cooperative learning; textual and contextual analysis including the analysis of conditional codes, representations, stereotypes, semiotic analysis of media texts of different genres; media text "transformation" that allows learners to "translate" a media text, such as a documentary, news release or commercial into one of the print genres, such as a newspaper article or a short story; role-playing and simulation methods when students create their own reports using the programs "iMovie" or "Moviemaker" on the topic of ethnic discrimination and intolerance, etc.

\section{Conclusion}

The comparative analysis of Russian and foreign approaches to promoting interethnic tolerance among university students through media education have enabled us to define the media education methods, forms, technologies and approaches aimed at fostering interethnic tolerance that can become a basis for further development in Russian media education:

- as our research has shown, the main material for studying the issues of interethnic dialogue, the culture of different peoples and ethnic groups are feature films and documentaries, websites, social networks, television programs, articles in newspapers and magazines. Development of analytical skills and critical thinking skills, comprehension and interpretation of media production of various types and genres, media creative and media project activities are of fundamental importance for studying and comprehending interethnic tolerance by student youth;

- when studying and analysing media culture about interethnic tolerance, the main goals of education are promoting students' civic responsibility and citizenship, developing their legal culture. To this end, students are taught the legal framework for ensuring interethnic tolerance: the main provisions of the State National Policy of the Russian Federation, the role of interfaith and interethnic dialogue in ensuring cultural diversity. The methods of case study, social testing, discussions, debates and reflection are actively used to develop students' media competence;

- the analysis of media production of different types and genres is one of the leading approaches in fostering university student's interethnic tolerance. This process is traditionally based on the key media education concepts related to defining the source, typology, perception, topics, and representation of media texts. Reliance on the concepts of media agencies, media categories, media technologies, media languages, media audiences, media representations;

- the research findings and the model for fostering students' interethnic tolerance through media education have enabled us to launch a university course for students "Promoting interethnic tolerance through media education" which can be used in teaching students the attitudes of interethnic tolerance.

\section{Acknowledgements}

This research is funded by the grant of the Russian Foundation for Basic Research (RFBR, project No. 19-013-00030) at the Rostov State University of Economics. Project theme: "Issues of Student Youth Interethnic Tolerance Reflected in Russian and English-Language Media Education of the Post-Soviet Period (1992-2020)". Head of the project is I.V. Chelysheva.

\section{References}

Alekhina, Anikina, 2019 - Alekhina, S.V., Anikina, I.A. (2019). Vospitanie tolerantnosti v molodezhnoj srede: uchebno-metodicheskoe posobie [Teaching tolerance in the youth environment: teaching aid]. Borisoglebsk. [in Russian] 
Apanasyk, 2013 - Apanasyk, L.A. (2013). Analiz regional'nyh programm preodolenija ksenofobii i jekstremizma $\mathrm{v}$ molodezhnoj srede [Analysis of regional programs for overcoming xenophobia and extremism among young people]. Vestnik Tambovskogo universiteta. 8(124). [Electronic resource]. URL: https://cyberleninka.ru/article/n/analiz-regionalnyh-programmpreodoleniya-ksenofobii-i-ekstremizma-v-molodezhnoy-srede [in Russian]

Bazalgette, 1992 - Bazalgette, C. (1992). Key Aspects of Media Education. In: Alvarado, M., Boyod-Barrett O. (ed.). Media Education: An Introduction. London: BFI Publishing: 198-205.

Buckingham, 2014 - Buckingham, D. (2014). Developing media literacy. Concepts, processes, and practices. London: English and Media Centre.

Chelysheva, Mikhaleva, 2019 - Chelysheva, I.V., Mikhaleva, G.V. (2019). Russian and foreign approaches to media education of young people in matters relating to interethnic tolerance. Media Education (Mediaobrazovanie). 59(3): 381-392. DOI: 10.13187/me.2019.3.381

Chelysheva, Mikhaleva, 2020 - Chelysheva, I., Mikhaleva, G. (2020). Content analysis of university students' interethnic tolerance reflected in Russian and English-language media education of the 21st century. Media Education (Mediaobrazovanie). 60(2): 222-237. DOI: $10.13187 / \mathrm{me} .2020 .2 .222$

Chelysheva, Mikhaleva, 2020 - Chelysheva, I., Mikhaleva, G. (2020). A model for developing university students' interethnic tolerance in the context of leading modern media education strategies in Russia and English-speaking countries. Media Education (Mediaobrazovanie). 60(4): 581-590. DOI: 10.13187/me.2020.4.581

Chelysheva, Mikhaleva, 2020 - Chelysheva, I., Mikhaleva, G. (2020). Content Analysis of University Students' Interethnic Tolerance Reflected in Russian and English-Language Media Education of the Post-Soviet Period (1992-2000). International Journal of Media and Information Literacy. 5(1): 15-30. DOI: 10.13187/ijmil.2020.1.15

Chimitova, 2011 - Chimitova, I.Z. (2011). Sredstva massovoj informacii kak faktor vozdejstvija na uroven' mezhjetnicheskoj tolerantnosti [Mass media as a factor of influence on the level of interethnic tolerance]. Vestnik BGU. 14. [Electronic resource]. URL: https://cyber leninka.ru/article/n/sredstvamassovoy-informatsii-kak-faktor-vozdeystviya-nauroven-mezhetnicheskoy-tolerantnosti [in Russian]

Domracheva et al., 2017 - Domracheva, S.A., Lezhnina, L.V., Morova, N.S. (2017). Teorija i praktika razvitija tolerantnosti sredstvami polikul'turnoj obrazovatel'noj platformy Marijskogo gosudarstvennogo universiteta [Theory and practice of developing tolerance by means of the multicultural educational platform of the Mari State University]. Yoshkar-Ola. [in Russian]

Fedorov, Mikhaleva, 2020 - Fedorov, A.V., Mikhaleva, G.V. (2020). Current trends in media and information literacy in research and scientific publications of the early 21st century. International Journal of Media and Information Literacy. 5(2): 153-163. DOI: 10.13187/ijmil. 2020.2.153

Frau-Meigs et al., 2017 - Frau-Meigs, D., Vetez, I., Flores Michel, J. (eds.) (2017). Public policies in media and information literacy in Europe. Cross-country comparisons. Oxon: Routledge/ECREA.

Frau-Meigs, Torrent, 2009 - Frau-Meigs, D., Torrent, J. (2009). Mapping media education policies around the world: Visions, programmes and challenges. New York: United Nations Alliance of Civilizations.

Gálik, 2019 - Gálik, S. (2019). On human identity in cyberspace of digital media. EJTS European Journal of Transformation Studies. 7 (2): 33-44.

Gálik, 2020 - Gálik, S. (2020). Philosophical Reflection of the Influence of Digital Media on Current Education. Media Education. 60(1): 100-106. DOI: 10.13187/me.2020.1.100

Garunova, Prosenyuk, 2018 - Garunova, N.N., Prosenyuk, O.A. (2018). Kommunikativnye praktiki v mezhnacional'nom vzaimodejstvii studencheskoj sredy vuzov juga Rossii [Communicative practices in interethnic interaction of the student environment of universities in the south of Russia]. In: Caucasian world: Problems of education, language, literature, history and religion. Materials of the International Scientific Conference dedicated to the 8oth anniversary of the Chechen State University. Makhachkala: 119-122. [in Russian]

Kačinová, 2018 - Kačinová, V. (2018). Media competence as a cross-curricular competence. Communication Today. 9(1): 38-57. 
Kolokoltseva, 2017 - Kolokoltseva, M.A. (2017). Formirovanie mezhjetnicheskoj tolerantnosti u studentov vuza sredstvami social'no-kul'turnoj dejatel'nosti [Development of ethnic tolerance among university students by means of social and cultural activities]. Vestnik VSU. 4: 62-65. [in Russian]

Livingstone, 2018 - Livingstone, S. (2018). From digital literacy to critical digital literacy. London: LSE Research Online.

Lukin, 2015 - Lukin, A.K. (2015). Stanovlenie identichnosti i tolerantnosti v uslovijah polikul'turnogo obrazovanija: monografija [Education for identity and tolerance in the context of multicultural education: monograph]. Krasnoyarsk. [in Russian]

Media..., 2012 - Media Awareness Network Releases New Program to Address Bias and Hate in Media. [Electronic resource]. URL: https://www.globenewswire.com/news-release/2012/03/28/ 1360119/o/en/Media-Awareness-Network-Releases-New-Program-to-Address-Bias-and-Hate-inMedia.html

Mikhaleva, 2019 - Mikhaleva, G.V. (2019). Teaching students how to analyze the impact of advertising media messages in the EFL classroom. International Journal of Media and Information Literacy. 4(2): 42-49. DOI: 10.13187/ijmil.2019.2.42

Petranová et al., 2017 - Petranová, D., Hossová, M., Velický, P. (2017). Current development trends of media literacy in European Union countries. Communication Today. 8(1): 52-65.

Ranieri, 2016 - Ranieri, M. (ed.) (2016). Populism, media and education: challenging discrimination in contemporary digital societies. London: Routledge.

Reineck, Lublinski, 2015 - Reineck, D., Lublinski, J. (2015). Media and information literacy: A human rights-based approach in developing countries. Bonn: DW Akademie.

Šupšáková, 2016 - Šupšáková, B. (2016). Media education of children and youth as a path to media literacy. Communication Today. 7(1): 32-51.

Tolstoukhova, 2019 - Tolstoukhova, I.V. (2019). Formirovanie mezhjetnicheskoj tolerantnosti $\mathrm{u}$ studentov vuza [Formation of interethnic tolerance among university students]. In: Modern ethnic processes in Central Asia: problems and prospects, 1. [Electronic resource]. URL: https://cyberleninka.ru/article/n/formirovanie-mezhetnicheskoy-tolerantnosti-u-studentovvuza [in Russian]

Worsnop, 2004 - Worsnop, C.M. (2004). Media Literary Through Critical Thinking. Teacher Materials. [Electronic resource]. URL: https://mediaeducation.ucoz.ru/load/o-o-o-1092-20 